\title{
Impact of Calcium Source on Modification of Properties of Saline-Sodic Soils
}

\author{
M.K. Abd El-Fattah \\ Soil Science Department, Faculty of Agriculture, Zagazig, \\ University, Zagazig, Egypt.
}

\begin{abstract}
A SOIL column (30-cm long and 16-cm inside diameter) $A$ experiment was conducted to study the effect of calcium source on reclaiming a saline sodic clay loam soil collected from Sahl ElTina, northern Sinai, Egypt. The calcium sources were agricultural gypsum "AG", phosphogypsum "PG" and calcium chloride "CC". Amendments were thoroughly mixed with soil. Leaching was done using the intermittent method so as to add portions to the already saturated soil columns. Six leachates of equal volumes were collected. At the end of experiment EC, pH, SAR, ESP and bulk density of soil decreased compared with the initial values which were $24.9 \mathrm{dSm}^{-1}$, $8.78,26.3,40.25$ and $1.42 \mathrm{Mgm}^{-3}$, respectively. Respective values at termination of experiment were for CC: $2.72 \mathrm{dSm}^{-1}, 8.12,3.40,3.79$ and1.23 $\mathrm{Mgm}^{-3}$; for PG: $3.37 \mathrm{dSm}^{-1}, 7.88,4.78,5.85$ and $1.27 \mathrm{Mgm}^{-3}$, for AG: $3.60 \mathrm{dSm}^{-1}, 8.02,4.94,6.08$ and $1.32 \mathrm{Mgm}^{-3}$, for control: 5.41 $\mathrm{dSm}^{-1}, 8.20,6.05,7.75$ and $1.33 \mathrm{Mgm}^{-3}$. All amendments were greater efficiencies as compared with control treatment. With only few of exceptions the order of efficiency of amendments was CC > PG > AG. This reflects the high solubility of $\mathrm{CC}$ rendering it the most readily available source of soluble $\mathrm{Ca}^{2+}$. Concerning PG and AG, results show that, PG was of a relatively greater effect on reducing EC, $\mathrm{pH}, \mathrm{SAR}$, ESP and bulk density. This indicates high $\mathrm{Ca}^{2+}$ release from PG due to its more acidity. The study suggests that leaching using $\mathrm{Ca}^{+2}$ sources amendments improves physico-chemical properties of saline sodic soils especially CC followed by PG and AG.
\end{abstract}

Keywords: Saline sodic soils, Chemical amendments, Agricultural gypsum, Phosphogypsum, Calcium chloride.

In Egypt, improving salt affected soils is an important part in the agricultural security program. Saline-soils contain excess soluble salts, and sodic soils contain excess exchangeable sodium. Such soils tend to occur mainly in arid zones. Aims at removal of excess salts out of the root zone or away to the drainage system and getting rid of sodicity by replacement of exchangeable sodium by calcium as well as removing sodium carbonates if presents. The removal of salts is carried out by leaching. The amount of leaching water depends on initial soil salinity level, applied water technique, and soil type. Water suitable for irrigation is normally suitable for reclamation. Therefore, it is important to have reliable estimates of the required amount of leaching water needed to reduce soil salinity/sodicity to a desirable level (Mamoun et al., 2012). 
Chemical amendments used for reclamation process be broadly grouped into three categories: totally soluble calcium salts, such as $\mathrm{CaCl}_{2}$, acids or acid forming substances, such as sulfuric acid, iron sulfate, aluminum sulfate, pyrite, ... etc and finally calcium salts of low solubility (ground lime stone). The suitability of one or another amendment for reclamation of saline or saline sodic soil largely depends on the nature of the soil and cost consideration (FAO, 1988).

Gypsum $\left(\mathrm{CaSO}_{4} \cdot 2 \mathrm{H}_{2} \mathrm{O}\right)$ is commonly used for reclamation of saline-sodic and sodic soils and to a lesser extent calcium chloride $\left(\mathrm{CaCl}_{2} \cdot 2 \mathrm{H}_{2} \mathrm{O}\right)$, and sulfuric acid $\left(\mathrm{H}_{2} \mathrm{SO}_{4}\right)$. The first two amendments provide a direct source of calcium ions $\left(\mathrm{Ca}^{2+}\right)$ to replace exchangeable sodium, whereas sulfuric acid increases the dissolution of calcite in soil (Mace et al., 1999).

The choice of an amendment depends upon its effectiveness and crop growth and the relative costs. The time required for amendment is also a consideration in the choice. Because of its high solubility, calcium chloride is the most effective source of soluble $\mathrm{Ca}^{+2}$ but it is rarely used because of its high cost (FAO, 1988).

Carter and Robbins (1978) reported that excessive salts in soil could be removed from soil profiles by passing $300-\mathrm{mm}$ depth of water per meter depth of soil. FAO (1976) stated that for leaching of salts a 300-mm depth of water leached through a $300-\mathrm{mm}$ depth of soil should remove about $80 \%$ of the chloride. Feize (1998) found that application of the first 600-mm water depth (i.e., $6000 \mathrm{~m}^{3} \mathrm{ha}^{-1}$ ) decreased initial soil salinity and sodicity within $500-\mathrm{mm}$ soil depth.

Abou Yuossef (2001) applied phosphogypsum and found that pH, EC, ESP and bulk density decreased with increasing PG rate. Also hydraulic conductivity, total porosity, mean weight diameter of soil aggregates, geometric mean diameter and water stable aggregates increased. Ahmad et al. (2001) and Abd ElFattah (2006 and 2011) reported that EC, ESP, SAR, pH and bulk density decreased whereas hydraulic conductivity and infiltration rate increased with gypsum application. Singh and Bajwa (1991)and Khalifa et al. (1994) applied excessive gypsum for reclamation of sodic soil and observed a quick removal of soluble sodium with a decreased ESP and $\mathrm{pH}$.

Salim et al. (2002) carried out field experiments using gypsum and calcium chloride (commercial material) to compare the relative efficiency for reclamation of sodic soils cultivated with wheat and rice. Results showed a significant increase in crop yields. The main objective of the current study is to assess the impact calcium sources such as agricultural gypsum, phosphogypsum and calcium chloride on modification of properties of saline-sodic soils using columns of soil. 


\section{Material and Methods}

Soil sampling

The saline-sodic soil used in the study was collected from Sahl El-Tina, Northern Sinai, Egypt. Physicochemical characteristics of the soil are presented in Table 1. Water used for leaching has of an EC of $1.5 \mathrm{dSm}^{-1}$.

TABLE 1. Physical and chemical properties of studied soil.

\begin{tabular}{|c|c|}
\hline Property & Value \\
\hline $\begin{array}{ll}\text { Particle size distribution and soil texture: } \\
-\quad \text { Clay } \% \\
-\quad \text { Silt } \% \\
-\quad \text { Sand } \% \\
-\quad \text { Texture } \\
\end{array}$ & $\begin{array}{c}35.6 \\
31.9 \\
32.5 \\
\text { Clay loam }\end{array}$ \\
\hline $\begin{array}{ll}\text { Soil moisture characteristics [\%]: } \\
-\quad \text { Saturation percent } \\
-\quad \text { Field capacity } \\
-\quad \text { Wilting percentage } \\
\end{array}$ & $\begin{array}{l}62.1 \\
31.1 \\
15.5 \\
\end{array}$ \\
\hline $\begin{array}{ll}\text { Density and porosity: } \\
-\quad \text { Bulk density }\left[\mathrm{Mgm}^{-3}\right] \\
-\quad \text { Total porosity }[\%]\end{array}$ & $\begin{array}{l}1.42 \\
46.4 \\
\end{array}$ \\
\hline Organic matter $\left[\mathrm{g} \mathrm{kg}^{-1}\right]$ & 3.80 \\
\hline $\mathrm{CaCO}_{3}\left[\mathrm{~g} \mathrm{~kg}^{-1}\right]$ & 159.0 \\
\hline 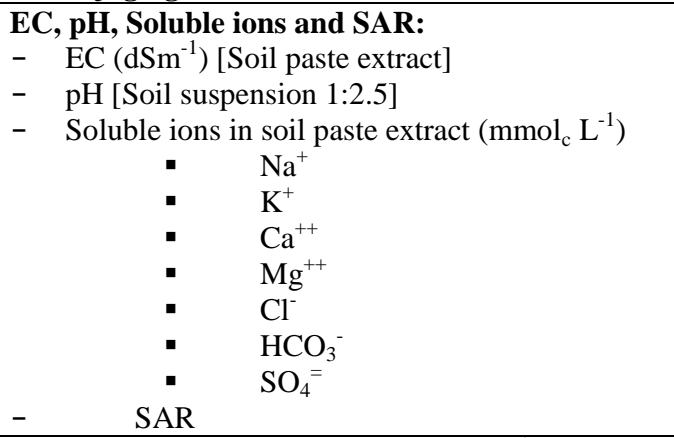 & $\begin{array}{c}24.90 \\
8.78 \\
\\
195.9 \\
4.8 \\
15.6 \\
95.8 \\
240.3 \\
2.2 \\
66.6 \\
26.3\end{array}$ \\
\hline $\begin{array}{cl}\text { Exchangeable cations, CEC }\left[\mathbf{c m o l}_{\mathbf{c}} \mathbf{~ k g}^{-1} \text { ] }\right. & \text { and ESP } \\
: & \mathrm{Na}^{+} \\
: & \mathrm{K}^{+} \\
: & \mathrm{Ca}^{++} \\
: & \mathrm{Mg}^{++} \\
: & \mathrm{CEC} \\
& \mathrm{ESP}\end{array}$ & $\begin{array}{l}10.38 \\
2.86 \\
4.56 \\
7.99 \\
25.79 \\
40.25\end{array}$ \\
\hline
\end{tabular}

\section{Experimental}

The Experimental design was a randomized complete block in 3 replicate. There were four treatments assessing 3 amendments. They were as follows: control "no treatment", agricultural gypsum "AG", phosphogypsum "PG" and calcium chloride "CC". PVC cylindroids tubes of 40-cm height and 16-cm inside 
diameter were used to contain the soil columns. The bottom of each tube was sealed with perforated a mesh nylon screen and glass wool. Acid-washed inert sand was placed on the tube bottom to make a 5-cm layer of the column. Such arrangement allowed for 5-cm on top of soil column to give sufficient space for addition of water for the leaching process.

\section{Addition of amendments}

Gypsum requirements (GR) are the amount of gypsum required for reclamation in order to decrease ESP from its initial value to a required value. In the current study it is calculated to decrease initial ESP from 40.25 to 10 for the upper 30-cm soil depth. The amount equivalent to GR using calcium chloride " $\mathrm{CaCl}_{2} .2 \mathrm{H}_{2} \mathrm{O}$ " is $0.85 \mathrm{GR}(\mathrm{FAO}, 1988)$. The experiment included four treatments which were as follows (Table 2).

TABLE 2. Properties of amendments and their applied amount.

\begin{tabular}{lcccc}
\hline \multicolumn{1}{c}{ Treatments } & $\begin{array}{c}\text { pH } \\
\mathbf{1 : 1 0}\end{array}$ & $\begin{array}{c}\mathbf{C a}^{\mathbf{2 +}} \\
\mathbf{g . k g}^{-\mathbf{1}}\end{array}$ & $\begin{array}{c}\text { Purity } \\
{[\%]}\end{array}$ & $\begin{array}{c}\text { Amount } \\
{\left[\mathbf{M g . f e d}^{-\mathbf{1}} \text { ] }\right.}\end{array}$ \\
\hline Control & ----- & ---- & ---- & 0.00 \\
AG & 7.80 & 227.9 & 98 & 13.69 \\
PG $^{*}$ & 2.67 & 100.5 & 65 & 20.64 \\
CC & 8.00 & 269.4 & 99 & 11.75 \\
\hline
\end{tabular}

*obtained mostly as by product of super phosphate manufacture.

Calculated amount of amendments were mixed thoroughly with soil. After mixing with amendments, the soils were leached with water having EC $1.5 \mathrm{dSm}^{-1}$, the amount of water was supplied using intermittent leaching method; water portions of $5-\mathrm{cm}$ depth over soil surface. Water portions were added to the already saturated soil columns. Obtained leachates were equal to the added portions. Leachates were collected and analyzed for salinity. Termination of leaching was done after collecting six leachates, each one equals a water depth of $5-\mathrm{cm}$, therefore leachates volumes were similar.

\section{Methods used for analysis}

Following termination of leaching, each soil columns were separated into three equal segments. Soil of each segment was analyzed according to the methods described by the FAO (1988).

\section{Results and Discussion}

\section{Salt removal}

Salt removal as affected by leaching and different amendments are illustrated in Fig. 1. Soluble salts removed in leachates depended on the number of leachates. There was a considerable decrease in EC particularly following the $1^{\text {st }}$ leachate. From the $3^{\text {rd }}$ leachate onwards, the decrease was rather moderate. 
This shows that the amount of added water which made the first leachate was capable of removing the majority of the readily soluble salts and mobile ions such as $\mathrm{Cl}^{-}$and $\mathrm{Na}^{+}$, whether the soils were amended or not.

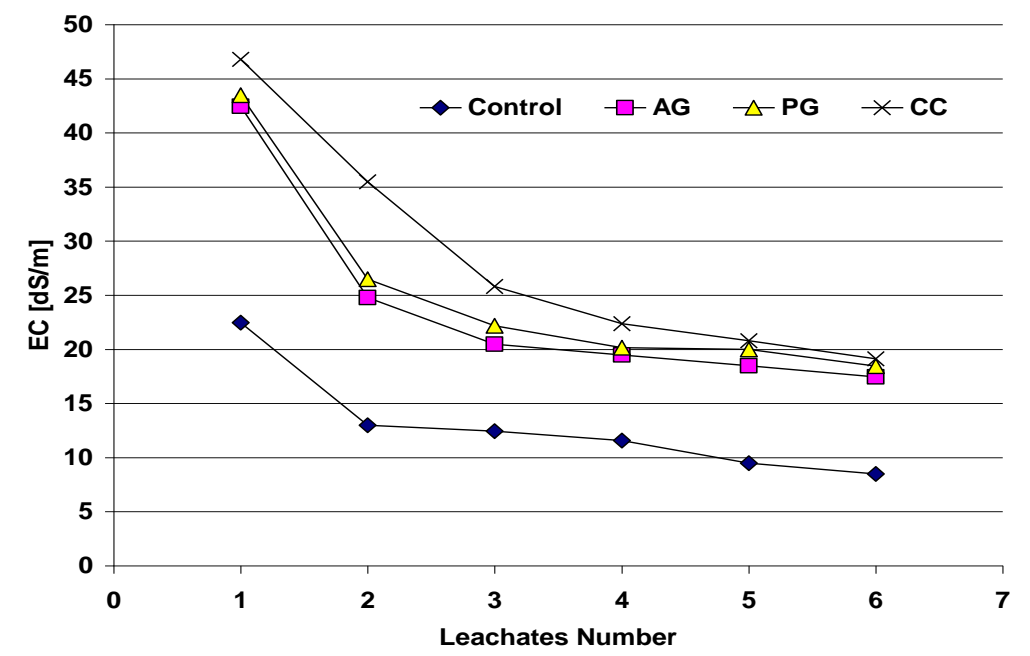

Fig. 1. Salt removal as affected by leaching and different amendments (i.e., Agricultural gypsum "AG", phosphogypsum "PG" and calcium chloride "CC").

Concerning the effect of amendments on salt leaching, the most effective material was calcium chloride. Treating soil with amendments resulted in efficiency of salt removal by $120.1,94.6$ and $84.9 \%$ due to CC, PG and AG, respectively compared with leaching only (control). Efficiency of treatments was $\mathrm{CC}>\mathrm{PG}>\mathrm{AG}>$ control.

Dissociation of slightly soluble salts (such as $\mathrm{CaSO}_{4}$ and $\mathrm{CaCO}_{3}$ ) and the desorbed exchange ions released from the exchange complex would further supply the soil solution with a soluble ions especially, $\mathrm{Na}^{+}, \mathrm{Ca}^{++}, \mathrm{SO}_{4}={ }^{2}, \mathrm{HCO}_{3}{ }^{-}$ and $\mathrm{CO}_{3}{ }^{2}$. During the first period of leaching the soluble salts leached from the soil column were mainly $\mathrm{NaCl}$ and $\mathrm{Na}_{2} \mathrm{SO}_{4}$ causing a high $\mathrm{EC}$ values while during the second period, the leached salts would include $\mathrm{NaHCO}_{4}$ and finally $\mathrm{Na}_{2} \mathrm{CO}_{3}$. The decreasing salinity was less considerable from the $3^{\text {rd }}$ leachate onwards. Amended treatments caused greater rates of decrease in salinity than non-amended ones. This indicates a favorable effect of amendments on the leacheability through improving the physical properties of the soil.

\section{Soil salinity}

Soil salinity after the six leachates is shown in Table 3 and Fig. 2. The initial soil salinity was of $24.90 \mathrm{dSm}^{-1}$ (in soil paste extract), decreased upon leaching to reach EC values of $5.41,3.60,3.37$ and $2.72 \mathrm{dSm}^{-1}$ for treatments of the 
control, AG, PG and CC, respectively. Efficiency of amendments in reclamation was of the following order $\mathrm{CC}>\mathrm{PG}>\mathrm{AG}$. Salinity in the upper layer was lower than in the lower ones.

TABLE 3. Some properties of soil at the end of experiment.

\begin{tabular}{|c|c|c|c|c|c|c|}
\hline $\begin{array}{c}\text { Treatments } \\
{[\mathrm{A}]}\end{array}$ & $\begin{array}{c}\text { Soil depth } \\
{[\mathrm{B}]}\end{array}$ & $\mathbf{p H}$ & $\begin{array}{c}E C \\
\mathrm{dSm}^{-1}\end{array}$ & SAR & ESP & $\begin{array}{c}\text { Bulk } \\
\text { density }\end{array}$ \\
\hline \multirow{4}{*}{ Control } & $0-10$ & 8.21 & 5.21 & 5.94 & 7.58 & 1.35 \\
\hline & $10-20$ & 8.20 & 5.44 & 6.07 & 7.77 & 1.32 \\
\hline & $20-30$ & 8.20 & 5.59 & 6.15 & 7.89 & 1.33 \\
\hline & Mean & 8.20 & 5.41 & 6.05 & 7.75 & 1.33 \\
\hline \multirow{4}{*}{$\begin{array}{l}\text { Agricultural } \\
\text { gypsum }\end{array}$} & $0-10$ & 7.99 & 3.56 & 4.91 & 6.04 & 1.31 \\
\hline & $10-20$ & 8.00 & 3.60 & 4.94 & 6.08 & 1.32 \\
\hline & $20-30$ & 8.06 & 3.63 & 4.96 & 6.11 & 1.32 \\
\hline & Mean & 8.02 & 3.60 & 4.94 & 6.08 & 1.32 \\
\hline \multirow{4}{*}{ Phosphogypsum } & $0-10$ & 7.86 & 3.33 & 4.75 & 5.80 & 1.25 \\
\hline & $10-20$ & 7.88 & 3.36 & 4.77 & 5.83 & 1.26 \\
\hline & $20-30$ & 7.91 & 3.42 & 4.81 & 5.90 & 1.31 \\
\hline & Mean & 7.88 & 3.37 & 4.78 & 5.85 & 1.27 \\
\hline \multirow{4}{*}{ Calcium chloride } & $0-10$ & 8.11 & 2.51 & 3.03 & 3.24 & 1.24 \\
\hline & $10-20$ & 8.12 & 2.80 & 3.55 & 4.02 & 1.23 \\
\hline & $20-30$ & 8.13 & 2.86 & 3.61 & 4.11 & 1.23 \\
\hline & Mean & 8.12 & 2.72 & 3.40 & 3.79 & 1.23 \\
\hline \multirow{4}{*}{$\begin{array}{l}\text { S Soil depth } \\
\mathrm{cm}\end{array}$} & $0-10$ & 8.04 & 3.65 & 4.66 & 5.66 & 1.29 \\
\hline & $10-20$ & 8.05 & 3.80 & 4.83 & 5.93 & 1.29 \\
\hline & $20-30$ & 8.08 & 3.88 & 4.88 & 6.00 & 1.30 \\
\hline & Mean & 8.06 & 3.78 & 4.79 & 5.86 & 1.29 \\
\hline \multirow{3}{*}{ LSD } & $\mathrm{A}$ & $\mathrm{NS}$ & 0.18 & 0.17 & 0.26 & 0.03 \\
\hline & B & 1.47 & 0.16 & 0.15 & 0.22 & NS \\
\hline & $\mathrm{A} \times \mathrm{B}$ & 2.95 & 0.32 & NS & NS & NS \\
\hline
\end{tabular}

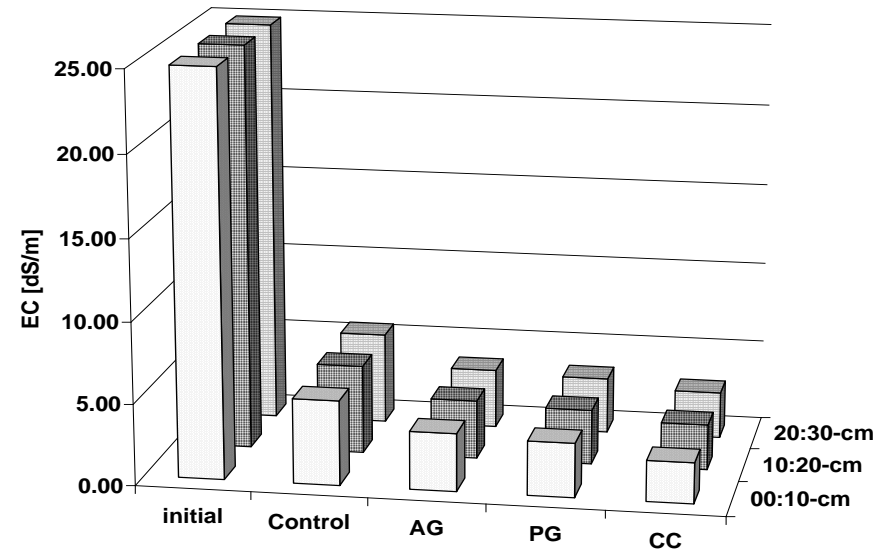

Fig. 2. Soil salinity in the different soil segments at the end of leaching (AG: Agricultural gypsum, PG: Phosphogypsum and CC: Calcium chloride).

Egypt. J. Soil Sci. 54, No. 1 (2014) 


\section{Soil $\mathrm{pH}$}

Data in Table 3 and Fig. 3 show that, the soil $\mathrm{pH}$ after leaching was lower as compared with before leaching. The initial soil $\mathrm{pH}$ of 8.78 was reduced to 8.20 , 8.02, 7.88 and 8.12 for the control, AG, PG and CC, respectively. Efficiency of treatments in decreasing soil $\mathrm{pH}$ is of the order: $\mathrm{PG}>\mathrm{AG}>\mathrm{CC}>$ control.

Both PG and AG were relatively of greater effect on reducing $\mathrm{pH}$ than $\mathrm{CC}$. The decrease in soil $\mathrm{pH}$ due to gypsum application is a manifestation of a replacement of sodium by calcium on the exchange complex, and formation of sulfate salts and a decrease in sodium concentration in soil. Moreover, gypsum solubility must have been enhanced because of the increased activity coefficient of calcium and sulfate as a result of increased ionic strength of solution and formation of the sodium sulfate ion pairs. Besides, $\mathrm{CO}_{2}$ evolved during leaching would form carbonic acids.

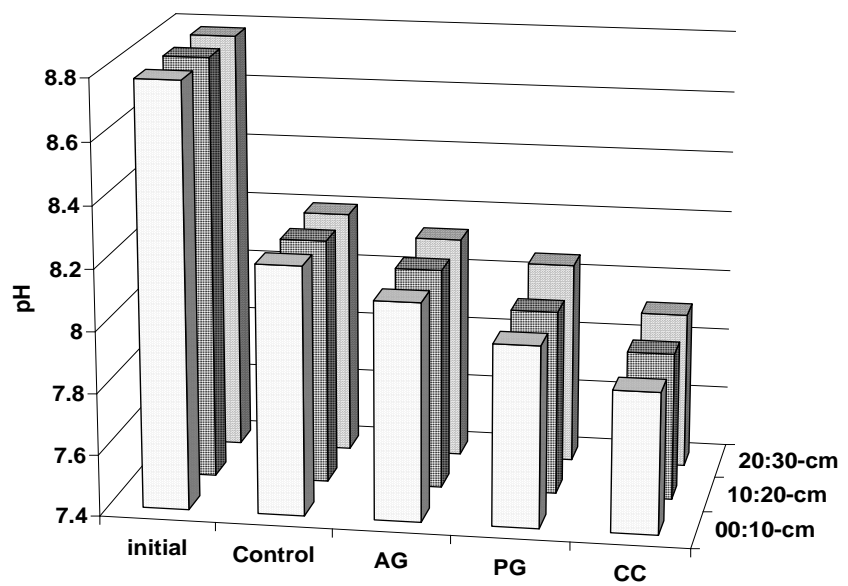

Fig. 3. $\mathrm{pH}$ in the different soil segments at the end of leaching experiment (AG Agricultural gypsum, PG: Phosphogypsum and CC: Calcium chloride).

\section{Soil sodicity}

Data in Table 3 and Fig. 4 show that the high initial value of SAR dropped sharply to become $6.05,4.94,4.78$ and 3.40 after the end of leaching process for the control, AG, PG and CC, respectively. Thus the comparative efficiency rating of amendments is as follows: $\mathrm{CC}>\mathrm{PG}>\mathrm{AG}$. The decrease in SAR reflects a removal of $\mathrm{Na}^{+}$from the soil colloidal complex. The results are in agreement with those of Chaudhry and Warkentin (1968).

Regarding ESP, Table 3 and Fig. 5 show decreases of 7.75, 6.08, 5.85 and $3.79 \%$ for control, AG, PG and CC, respectively. The high efficiency of CC is an indication of its solubility, which would give more of the most readily soluble $\mathrm{Ca}^{2+}$. The PG showed a relatively greater effect than AG in decreasing sodicity 
of soil. This may be explained by $\mathrm{Ca}^{2+}$ released from $\mathrm{PG}$ being higher than AG (of a $\mathrm{pH} 7.8$ ) due to greater acidity in $\mathrm{PG}$ (of a $\mathrm{pH} 2.67$ ). These results are in agreement with those of Abd El-Fattah (2006).

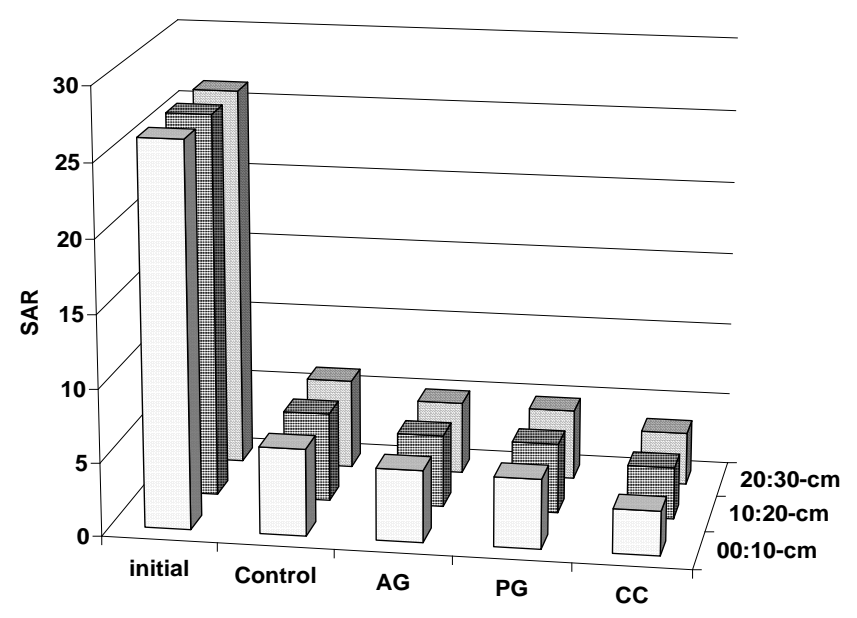

Fig. 4. SAR in the different soil segments at the end of leaching experiment (AG: Agricultural gypsum, PG: Phosphogypsum and CC: Calcium chloride).

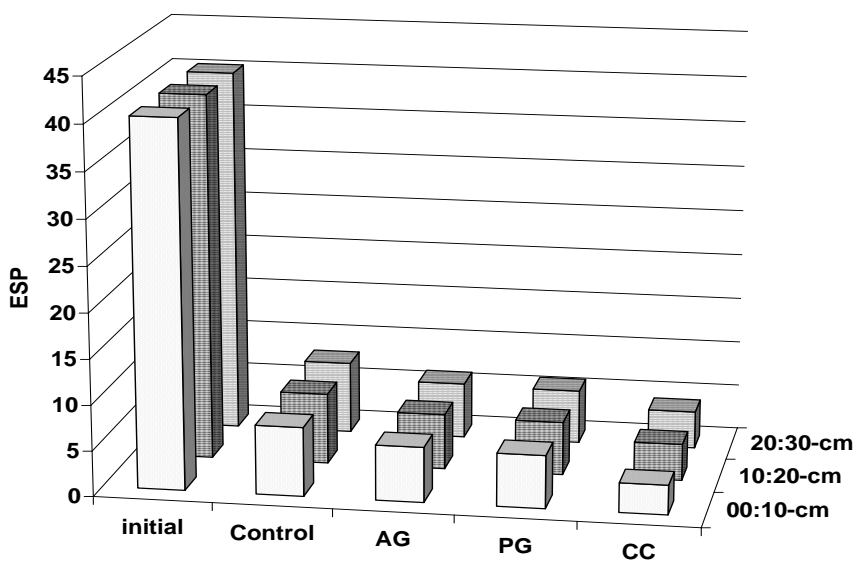

Fig. 5. ESP in the different soil segments at the end of leaching experiment (AG: Agricultural gypsum, PG: Phosphogypsum and CC: Calcium chloride).

Bulk density $(B D)$

Bulk density as affected by leaching with or without amendments is shown in Table 3 and illustrated in Fig. 6. Values of BD are significantly lower in

Egypt. J. Soil Sci. 54, No. 1 (2014) 
amended soils than in the non-amended ones. The lowest BD was recorded with calcium chloride "CC" followed by phosphogypsum "PG" then agricultural gypsum "AG". Leaching decreased BD by $6.33,7.04,10.50$ and $13.38 \%$ due to non-amended, AG, PG and CC, respectively compared with that of the initial soil (of $1.42 \mathrm{Mg} \cdot \mathrm{m}^{-3}$ ). The order efficiency of amendments was $\mathrm{CC}>\mathrm{PG}>\mathrm{AG}$.

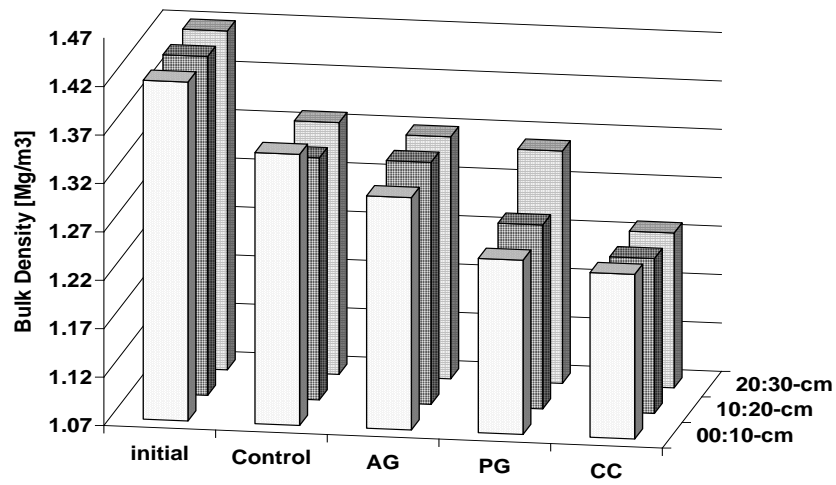

Fig. 6. Bulk density of the soil segments at the end of leaching experiment (AG: Agricultural gypsum, PG: Phosphogypsum and CC: Calcium chloride).

\section{Conclusion}

Application of chemical amendments enhanced reclamation of the salinesodic soil and caused more decreases in salinity as well as sodicity to a considerable extent. The studied treatments could be arranged in the following order, calcium chloride $(\mathrm{CC})>$ Phosphogypsum $(\mathrm{PG})>$ agricultural gypsum (AG). The solubility of these sources in water, particularly calcium chloride is a result of such effect. Phosphogypsum (PG) showed a relatively greater effect in decreasing soil EC, $\mathrm{pH}, \mathrm{SAR}$, ESP and bulk density compared with agricultural gypsum (AG) reflecting more $\mathrm{Ca}^{2}$ released from the former, probably due to its acidity. This study suggests that leaching using $\mathrm{Ca}^{+2}$ sources amendments (i.e., AG, PG and CC) would improve the chemical and physical properties of saline sodic soils.

\section{References}

Abd El-Fattah, M.K. (2006) Some approaches for reclaiming and restoring degraded soils. M.Sc. Thesis, Fac. of Agric., Zagazig Univ., Egypt.

Abd El-Fattah, M.K. (2011) Some biological and chemical methods for salt affected soils reclamation. Ph.D. Thesis, Fac. of Agric., Zagazig Univ., Egypt. 
Abou Youssef, M.F. (2001) Use phosphogypsum fortified as a soil amendment for saline sodic soil in El-Salhiya plain. Zagazig J. Agric. Res. 28: 889 -911.

Ahmad, M., Hussain, N., Salim, M. and Niazi, B.H. (2001) Use of chemical amendments for reclamation of saline-sodic soils. Int. J. Agri. Biol. 3 (3): 305-307.

Carter, D.L. and Robbins, C.W. (1978) Salt Outflows from new and old irrigated lands. Soil Sci. Soc. Am. J. 42 (4): 627-632.

Chaudhry, G.H. and Warkentin, B.P. (1968) Studies on exchange of sodium from soils by leaching with gypsum. Soil Sci. 105: 190-97.

FAO (1988) Salt affected soils and their management. Soils Bulletin No. 39 Roma.

FAO (1976) A Framework for Land Evaluation. FAO Soils Bulletin No. 32, Rome, Italy.

Feize, M. (1998) Reclamation of saline sodic soils by leaching with different water qualities. Proceeding of the International Symposium on Sustainable Management of Salt Affected Soils in the Arid Ecosystem and FAO-workshop (network group) on integrated management of sustainable use of salt affected soils. Cairo, Egypt, 21-26 September, 1997, pp. 378-385.

Khalifa, M.R., Koriem, M.A., Ibrahim, M.M. and Hammad, E. (1994) Reclamation of saline sodic soils by leaching with drainage water and gypsum application. Monofiya Agric. Res. (19): 685-698.

Mace, J.E., Amrhein, C. and Oster, J.D. (1999) Comparison of gypsum and sulfuric acid for sodic soil reclamation. Arid Soil Res. Rehab. 13:171-188.

Mamoun, A., Gharaibeh, N.I.E. and Shady, H.S. (2012) Desalination and desodification curves of highly saline-sodic soil amended with phosphoric acid and by-product gypsum. International Journal of Environmental Science and Development 3 (1): 39-42.

Salim, A., Ahmad, M., Hussain, N., Niazi, R. and Malik, K.A. (2002) Role of soil amendments in saline agriculture prospects for saline agriculture. Book: Prospects for saline agriculture, ISBN: 1-4020-0620-9, Record Number: 20033092275, pp. $433-$ 438.

Singh, H. and Bajwa, M.S. (1991) Effect of sodic irrigation and gypsum on the reclamation of sodic soil and growth of rice and wheat plants. Indian Agricultural Water Management 20 (2): 163-171. 


\section{تأثير مصدر الكالسيوم على تعديل خواص الأراضي الملحية الصودية$$
\text { قسم علوم الأراضي ـ كلية الزراعة - جامعة الزقازيق - الزقازيق ـ مصر . }
$$

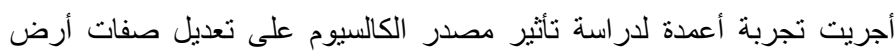
ملحبة صودية ذات قوام طيني طيبي حيث تم تجميع التربة من منطقة سهل الطينة الطينة

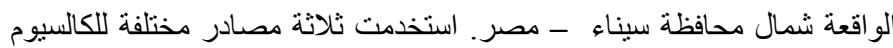

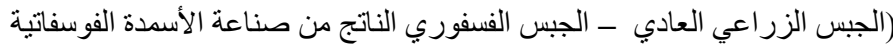

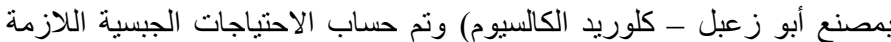

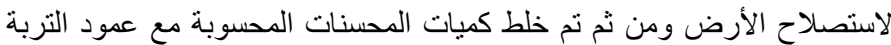

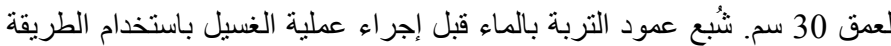

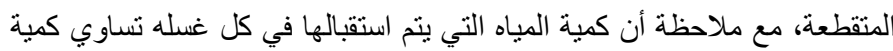

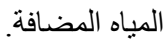

أظهرت النتائج أن كل المعاملات أدت إلى انخفاض درجة التوصيل الكهربي

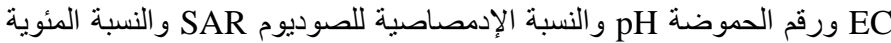

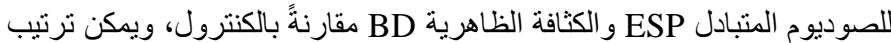

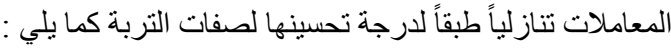
كلوريد الكالسيوم > الجبس الفسفوريا لرجيا > الجبس الزراعي العادي > الكنترول

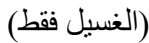

و يمكن أن تُفسر النتيجة السابقة إلى أن كلوريد الكالسيوم أكثر ذوباناً في الماء

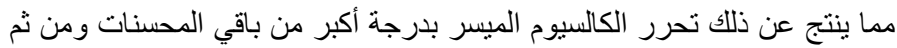

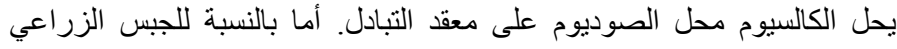

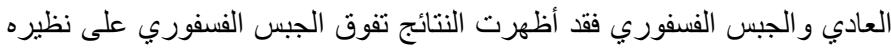

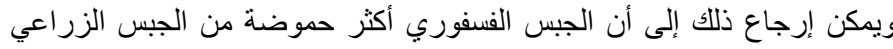

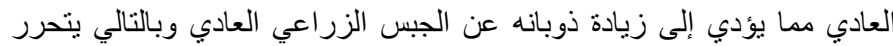

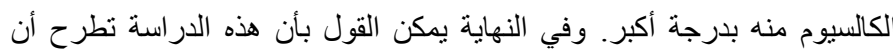

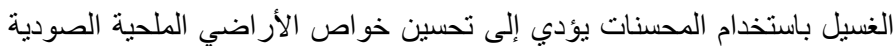
وأن مصدر الكالسيوم يؤثر على درجة الاستصلاح. 